\title{
CASE STUDY: EARLY OUTCOMES AND LESSONS LEARNT FROM A RECENTLY TRANSLOCATED WOODLAND ECOSYSTEM ${ }^{1}$
}

\author{
R. Neil Humphries, ${ }^{2}$ Aude Delmer, and Geraint Hopkins
}

\begin{abstract}
The translocation of wildlife habitats remains controversial in the UK and as a last resort where prime ecosystems are involved. None is more contentious as those for woodland designated as 'ancient semi-natural woodland' (i.e., have been in situ for some 400 years or more). There are very few accessible and informative first-hand reports of woodland translocation schemes from which to learn. In this paper we discuss the outcomes of the monitoring of vascular plants and invertebrates one year after translocation of part of an ancient semi-natural woodland, following the granting of planning consent to extend a nationally important aggregate resource. The monitoring in the first year following translocation has been of particular importance as it identified that the representative species, which are needed to re-establish and develop into similar woodland communities to those of the donor, are present. It demonstrates that the physical translocation of the "whole woodland' vascular plant assemblage is more feasible than previously canvassed, and something that is equivalent to familiar woodland practices of clear-felling operations or coppice rotations. It also determined the need and focus for the proactive control of invasive species that will be needed to achieve the longer-term objective in the vicinity of both the donor woodland and the receptor site, prior to, during and after translocation. The findings are timely and of relevance, beyond the mineral extraction industry, to infrastructure and other built developments involving important woodland ecosystems.
\end{abstract}

Additional Key Words: aggregate quarries, Quercus woodland, invasive plant species, seed bank, proactive management

${ }^{1}$ Oral paper presented at the 2019 National Meeting of the American Society of Mining and Reclamation, Big Sky, MT. Welcome Back to Montana: The Land of Reclamation Pioneers, June 3-7, 2019. R. I. Barnhisel (Ed.) Published by ASMR, 1305 Weathervane Dr., Champaign, IL 61821.

${ }^{2}$ R. N. Humphries, Blakemere Consultants Ltd, Dorchester DT1 3RZ, UK. A. Delmer, Restoration Manager, Tarmac Ltd, Panshanger Park, Hertford SG14 2NA, UK. G. Hopkins, Construction Manager, Tarmac Ltd, Mountsorrel Quarry, Mountsorrel LE12 $8 \mathrm{GE}, \mathrm{UK}$.

DOI: http://dx.doi.org/10.21000/JASMR19030022 


\section{$\underline{\text { Introduction }}$}

The translocation of biologically important semi-natural habitats as mitigation for the facilitation of development has been and remains controversial in the UK (Bullock, 1998; McLean, 2001; Ryan 2013; The Woodland Trust, 2014), especially where they have been designated as being of national importance as Sites of Special Scientific Interest (SSSI) and/or Ancient Semi-Natural Woodlands (ASNW). The UK Government's current development control policies are presumptive against translocation as a means of obtaining a planning consent, and particularly in the case of ASNWs, unless the development is of overriding national importance, in the public interest, or of health or safety importance (UK Government, 2018). Past and recent examples of national interest are the construction of the Channel Tunnel (Helliwell et al., 1996) and the currently proposed high speed railway line (HS2) from London to Birmingham, Manchester, and Leeds which both affect ASNWs (UK Government, 2017), but also mineral reserves such as Magnesian Limestone (Park, 1989). In these circumstances, translocations may be seen as a form of partial compensation, and are usually not to be relied upon without other mitigation (Ryan, 2013; The Woodland Trust, 2014; High Speed 2 Limited, 2017). In any other circumstances, planning consent is unlikely to be granted for mineral development.

The strategic importance of Mountsorrel Quarry for the UK's infrastructure has been recognised by the recent granting of consent by the local Mineral Planning Authority to extend the lateral limit of mineral extraction to include small areas of remaining Buddon Wood (SSSI and ASNW) around the northern and southern quarry rims. To facilitate the granting consent within current planning framework, mitigation was provided in two ways,

i. off-setting the area of lost woodland with areas previously consented (i.e., would no longer be worked),

ii. the translocation of woodland soils and flora from the affected areas to initiate reestablishment on a newly created landform next to the quarry.

The objective of this paper is to consider some of the early outcomes of the first phase of translocation of the woodland from the northern quarry rim, the lessons learnt and their application to future translocation schemes. 


\section{Background}

\section{Mountsorrel Quarry}

Mountsorrel Quarry is one of the largest of its type in Europe and is of strategic UK importance as a source of hard-wearing aggregate suitable as rail ballast, which is distributed nationally via its rail-head (Aggregate Business, 2019). The source rock is a domed granodiorite intrusion of the Triassic Era (Haines and Horton, 1969). The excavation footprint covers about $3 / 4 \mathrm{~km}^{2}$, it is 'cone-shaped' and has a diameter of about $1000 \mathrm{~m}$ at the current ground level and is about $253 \mathrm{~m}$ deep from the original ground level of the dome to its current lowest point of about $120 \mathrm{~m}$ below sea level. Stone extraction locally has a long history from its beginning in Roman times, with stone extraction from Mountsorrel Quarry starting in 1974 following the working-out of the adjacent Broad Hill and the smaller Hawcliffe, Cocklow Wood, and Nunckley Hill Quarries (Glassball Art Projects, 2012).

Mountsorrel Quarry (LAT 52.731135 LONG -1.1679840) is located in central England and to the north west of the city of Leicester. It lies on the eastern edge of an area known as Charnwood Forest comprising volcanic and metamorphic rocks originating in the Cambrian and later Eras. The area is of outstanding landscape, historical and ecological importance, comprising a patchwork of agricultural land and woodland in a rolling landscape with exposed granite peaks. Mountsorrel Quarry has been developed within one of the forested outcrops, Buddon Wood, but not without controversy because of its ecological and historical values as a designated SSSI and ASNW of a lineage probably preceding Saxon times. Whilst these designations did not prevent the early development of the Quarry in the 1970s, they are today a material consideration because of changes in national planning policies and to an extent that today there have to be exceptionally important reasons to allow quarry development to take place that affect SSSIs and/or ASNWs.

\section{Donor Woodland Types}

Buddon Wood is unusual in the English Midlands as it supports both lowland (National Vegetation Classification (NVC) W10 Quercus robur-Pteridium aquilinum-Rubus fruticosus woodland) and upland (NVC W16 Quercus spp.-Betula spp.-Deschampsia flexuosa woodland) types of oak woodland (Natural England, Undated; Rodwell, 1991). Both of these occur, with intermediary types, as a mosaic throughout Buddon Wood with the upland W16 type associated with locally occurring granite outcrops, and the lowland W10 with the deeper coverage of soils developed upon the granite or cover of glacial drift. Buddon Wood was 
clear-felled in the 1940s and current stands are from regenerated stumps which is evidence that this has happened in the past on a rotational basis.

The woodland to be translocated comprised representatives of both types, about 0.35 ha of W10 and 0.23 ha of W16. Prior to translocation (i.e., to provide a base-line) in the northern development area, North East Rim (NER), the donor woodland was mapped in July 2014, and an inventory of vascular species present was made from which the NVC types were determined. One area (NER5) of NVC W10 was identified along with three areas of W16 (NER 1, NER2, and NER4). A further small area, NER 3 (W10), was not needed to extend the workings and was left in situ. Each woodland was described using the standardised NVC methodology for woodland (Rodwell, 1991), comprising the listing of plant species occurring in the Canopy, Shrub, and Ground vegetation layers and the assignment of relative cover/abundance and constancy values. This information provided a reference point as to the pre-translocation type and condition.

\section{$\underline{\text { Translocation Method }}$}

The translocation of the woodland from the northern quarry rim was undertaken in two tranches in April and August 2017. Before this, the donor areas were prepared during the winter 2016-2017 by pollarding oak and birch trees greater than $30 \mathrm{~cm}$ diameter to about $1.5 \mathrm{~m}$ height and smaller trees and shrubs were cut near to ground level, with the 'brash' from both removed to the quarry side of the operations. In the case of the W10 woodland areas (5i-5iii), further preparation work (the strimming of bracken (Pteridium aquilinum) to ground level and its removal) was necessary (because of its seasonal growth) in advance of the August translocation.

The topsoil (with the in situ ground vegetation) and subsoil were recovered sequentially as a single digs to their natural depth and with any tree/shrub stumps and roots using tracked excavators (Volvo 360) with standard 'digging' buckets and loaded into articulated dumptrucks (Volvo A30) to be transported to the receptor area. The pollarded trees (referred to as 'monoliths') were lifted and transported in the same way.

The receptor area was on the lower slope of an overburden depository being raised in a former field alongside and facing the southern extent of Buddon Wood. The overburden was largely Permian marl cloaking the lower slopes and infilling deep waddis in the granite intrusion developed during the Triassic Era. 
The transported soils were sequentially spread over the overburden landform (on an area for area basis), using a tracked excavator (Volvo 360) with a long-reach (15m 'effective' reach) boom, into which the tree monoliths were 'planted.' The distribution of the donor NER areas is shown on Fig. 1. To integrate with the local distribution pattern of the naturally occurring woodland on the western slopes, the types from NER 4 and NER 5 were replaced as a mosaic (NER 4i andand 4ii, NER 5i, 5ii, and 5iii). Area 1A was placed and then dug-out when it was confirmed these were previously disturbed soils and the donor vegetation was not of the target NVC types.

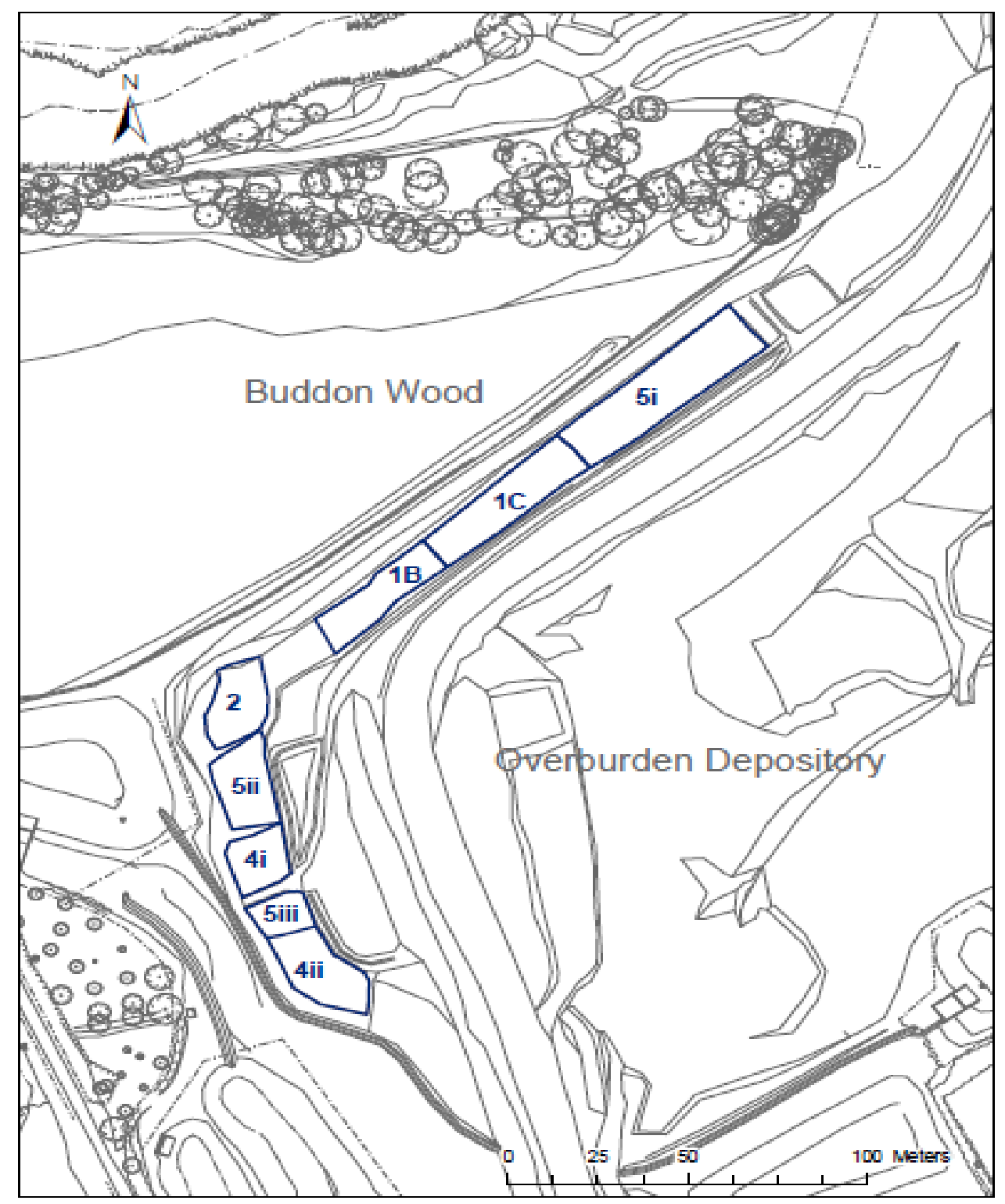

Figure 1. Layout of translocated woodland plots. 


\section{Monitoring}

The focus of the monitoring is upon the composition of the recovering ground flora and the invertebrate communities as being the most important biodiversity and conservation features of Buddon Wood (Natural England, Undated). The monitoring took place on 9th July 2018. The choosing of the date and frequency was determined by the consultant entomologist (A. Godfrey) and based on our previous 3 years of invertebrate monitoring within Buddon Wood. The choice also suited the optimal timing for the botanical survey as the flora comprises perennial species which are visible throughout the summer period.

\section{Botanical Monitoring}

The botanical monitoring comprised the listing of the woody species present either as translocated monoliths, seedlings, and regeneration from stump and root fragments, and a listing of herbaceous vascular plants forming the ground layer.

The detailed botanical monitoring of the ground layer followed the method (Rodwell, 2006) comprising the listing of all vascular plant species seen and their DAFOR abundance scores in each of the receptor areas (NER1B, 1C, 2, 4i, 4ii, 5i, 5ii, and 5iii). Following inspection of the collected data as a whole, it was aggregated into two distinct groupings, i) 1B, 1C, NER2, and NER4i and 4ii; and ii) NER5i, 5ii, and 5iii, these being representative of the pre-translocation W16 and W10 oak woodland types, respectively. Reference is made to the species lists compiled in 2014 for the affected parts of the woodland prior to translocation and the published generalised national/regional species lists (Rodwell, 1991).

\section{Invertebrate Monitoring}

The invertebrate monitoring comprised sweep-netting the vegetation in each of the receptor areas and listing in the field the conspicuous species in sub-samples taken from the sweeps within each receptor area. As for the botanical data, habitat types are used as reference models in which the recorded species are listed (Drake et al., 2007).

\section{$\underline{\text { Results }}$}

The following findings are for the two aggregated W10 and W16 woodland groupings 1215 months after the translocations in 2017.

\section{Botanical Monitoring}

Potential Tree-Shrub Layers. Almost all of tree monoliths within both translocated woodland types were sessile oak (Quercus petraea) (Table 1). The number of tree monoliths varied 
between the receptor areas according to their occurrence in their respective Donor areas ranging from none to 12 in number. More than half of the tree monoliths sprouted new shoots.

Table 1. Number of planted and resprouting tree monoliths.

\begin{tabular}{|l|l|l|l|l|}
\hline & \multicolumn{2}{|l|}{ Within W10 Areas } & Within W16 Areas \\
\hline Species & $\begin{array}{l}\text { Monoliths } \\
\text { Planted }\end{array}$ & $\begin{array}{l}\text { Monoliths Re- } \\
\text { sprouted }\end{array}$ & $\begin{array}{l}\text { Monoliths } \\
\text { Planted }\end{array}$ & $\begin{array}{l}\text { Monoliths Re- } \\
\text { sprouted }\end{array}$ \\
\hline $\begin{array}{l}\text { Quercus } \\
\text { petraea }\end{array}$ & 20 & 11 & 22 & 15 \\
\hline Betula pendula & 1 & 0 & 0 & \\
\hline $\begin{array}{l}\text { Fraxinus } \\
\text { excelsior }\end{array}$ & 0 & & 0 & 1 \\
\hline $\begin{array}{l}\text { Sorbus } \\
\text { aucuparia }\end{array}$ & 0 & & 1 & \\
\hline Unknown & 0 & & 0 & \\
\hline
\end{tabular}

Within the regenerating ground layer, a number of tree seedlings were counted (Table 2). In the W10 type the volunteer seedlings were mainly $Q$. petraea, whereas in the W16 there were numbers of both Q. petraea and silver birch (Betula pendula). The distribution and number of volunteer seedlings varied between the individual translocated areas with $Q$. petraea (24 no.) occurring in two of the W10 and two of the W16 areas, and B. pendula (39 no.) confirmed in two of the five W16 translocated areas, with only 1 seedling in the W10 areas.

Table 2. Number of volunteer tree seedlings within translocated areas.

\begin{tabular}{|l|l|l|}
\hline Species & $\begin{array}{l}\text { Number of Volunteer } \\
\text { Seedlings Within W10 } \\
\text { Areas }\end{array}$ & $\begin{array}{l}\text { Number of Volunteer } \\
\text { Seedlings Within W16 } \\
\text { Areas }\end{array}$ \\
\hline Quercus. petraea & 16 & 24 \\
\hline Betula pendula & 1 & 39 \\
\hline Fraxinus excelsior & 1 & 0 \\
\hline Sorbus aucuparia & 0 & 0 \\
\hline Unidentified & 6 & 12 \\
\hline
\end{tabular}

In addition to the above tree seedlings, other woody shrub layer species were recorded (Table 3). Of note were the presence of the invasive non-native tree, sycamore (Acer pseudoplatanus), and the invasive non-native (ornamental) shrub species of rhododendron/cherry laurel (Rhododendron ponticum/Prunus laurocerasus) and butterfly bush (Buddleja davidii). These were as scattered plants in the W16 translocated areas, whereas, in the W10 areas, only $B$. davidii was present. 
Some of the woody species recorded were within the Donor areas, but others were not previously recorded in the W16 woodland translocated areas, these included hazel (Corylus avellana), elder (Sambucus nigra), European gorse (Ulex europaeus), and the climber honeysuckle (Lonicera periclymenum) (Table 3). Whereas, in the W10 woodland areas these and other species were previously recorded, but were absent in the receptor areas. In the longer species lists, both receptor areas had the presence of respective NVC component species after translocation which were not recorded before. In the W10 receptor areas, some NVC species present in the Donor areas were not recorded after translocation. This is suspected to be an artefact of where the boundary between the two woodland types was drawn at the time of the surveys and translocations owing to a gradient over serval metres and difficulty of judging where one woodland becomes another type. This is the most likely explanation why there is more W10-like herbaceous and woody vegetation in the W16 woodland areas after translocation, and fewer in the W10 areas (Tables 3, 4, and 5).

Table 3. Tree and shrub species representative of NVC W10 and W16 woodlands\#.

\begin{tabular}{|c|c|c|c|c|}
\hline \multicolumn{3}{|c|}{ NVC W10 Listed Species } & \multicolumn{2}{|c|}{ NVC W16 Listed Species } \\
\hline $\begin{array}{l}\text { Donor and } \\
\text { Receptor }\end{array}$ & $\begin{array}{l}\text { Donor not } \\
\text { Receptor }\end{array}$ & $\begin{array}{l}\text { Not Donor but } \\
\text { Receptor }\end{array}$ & $\begin{array}{l}\text { Donor and } \\
\text { Receptor }\end{array}$ & $\begin{array}{l}\text { Not Donor but } \\
\text { Receptor }\end{array}$ \\
\hline $\begin{array}{l}\text { Quercus petaea, } \\
\text { Sambucus nigra }\end{array}$ & $\begin{array}{l}\text { Acer } \\
\text { pseudoplatanus, } \\
\text { Betula pendula, } \\
\text { Corylus } \\
\text { avellana, } \\
\text { Fraxinus } \\
\text { excelsior, } \\
\text { Lonicera } \\
\text { periclymenum, } \\
\text { Rhododendron } \\
\text { ponticum/ } \\
\text { Prunus } \\
\text { laurocerasus, } \\
\text { Ulex europaeus }\end{array}$ & $\begin{array}{l}\text { Buddleja } \\
\text { davidii }\end{array}$ & $\begin{array}{l}\text { Acer } \\
\text { pseudoplatanus, } \\
\text { Betula pendula, } \\
\text { Quercus } \\
\text { petraea, } \\
\text { Lonicera } \\
\text { periclymenum, } \\
\text { Rhododendron } \\
\text { ponticum/ } \\
\text { Prunus } \\
\text { laurocerasus }\end{array}$ & $\begin{array}{l}\text { Buddleja } \\
\text { davidii, Corylus } \\
\text { avellana, } \\
\text { Fraxinus } \\
\text { excelsior, Salix } \\
\text { cinerea subsp. } \\
\text { Oleifolia, } \\
\text { Sambucus } \\
\text { nigra, Ulex } \\
\text { europaeus }\end{array}$ \\
\hline
\end{tabular}

\# Rodwell, 1991

Ground Layer. Within the ground layer regenerating from the Donor W10 woodland a total of 67 vascular plant species were recorded and within the W16 translocated areas a total of 84 species were recorded (see tables below). It is this layer in the early stage in woodland regeneration that provides the initial physical ground cover. A notable feature of the regenerating ground layer in the individual translocated areas is the variety of component species at a low abundance. Only a few (constant) species within each woodland type occurred in all the translocation areas (these are denoted by underlining in the following 
Table 5. Herbaceous species associated with other types of woodland.

\begin{tabular}{|l|l|}
\hline Within W10 Areas - Receptor not Donor & Within W16 Areas - Receptor not Donor \\
\hline Torilis japonica, Veronica serpyllifolia & $\begin{array}{l}\text { Arctium minus, Carex pilulifera, Poa } \\
\text { trivialis, } \text { Rubus idaeus, } \text { Rumex sanguineus, } \\
\text { Silene dioica, Torilis japonica, Utica dioica, }\end{array}$ \\
\hline \begin{tabular}{l} 
Veronica serpyllifolia \\
\hline
\end{tabular}
\end{tabular}

Bold $=$ species frequent or greater abundance in any area of woodland type; Underlined = species occurred in all areas of woodland type.

On further inspection, using the New Flora of the British Iles (Stace, 1991) as an authoritative source, the non-NVC W10 and W16 plant species in the ground layer were grouped as to their typical habitat/vegetation associations, these were early succession/disturbed, grassland, and plant species of a 'wider' distribution.

Both the Donor woodland types had species associated with open ground/early successional communities (Table 6) and especially those associated with disturbed vegetation and soils having typical communities such as NVC OV13 Stellaria media-Capsella bursapastoris (Rodwell, 2000).

Table 6. Herbaceous species associated with early succession/disturbed land and occurring in all translocated areas and/or at frequent or greater abundance.

\begin{tabular}{|c|c|c|}
\hline \multicolumn{2}{|c|}{ Within W10 Areas } & Within W16 Areas \\
\hline Donor and Receptor & Receptor not Donor & Receptor not Donor \\
\hline Cirsium vulgare\# & 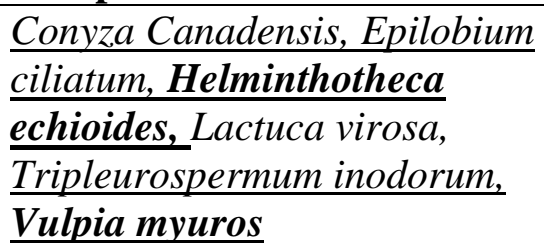 & $\begin{array}{l}\text { Cirsium vulgare\#, } \\
\text { Anisantha sterilis, Conyza } \\
\text { canadensis, Epilobium } \\
\text { ciliatum, Senecio viscosus, } \\
\text { Vulpia myuros }\end{array}$ \\
\hline
\end{tabular}

Less constant and frequent species: W10 Areas - Donor and Receptor Sonchus arvensis\#: Donor not Receptor Sisymbrium officinale\#, Sonchus oleraceus\#, Anagallis arvensis, Anisantha sterilis, Triticum aestivum: Receptor not Donor Rumex crispus\#, Sonchus asper\#, Papaver rhoeas\#, Rumex obtusifolius\#, Senecio vulgaris\#, Arenaria serpyllifolia, Cerastium fontanum, Epilobium montanum, Lactuca serriola, Papver somniferum, Persicaria maculosa, Reseda luteola, Sagina filicaulis, Senecio viscosus, Tanacetum parthenium, Tussilago farfara.

Less constant and frequent species: W16 Areas- Donor not Receptor Lactuca serriola, Papver somniferum, Tanacetum parthenium: Receptor not Donor Sonchus asper\#, Rumex crispus\#, Rumex obtusifolius\#, Senecio vulgaris\#, Sonchus arvensis\#, Sisymbrium officinale\#, Sonchus oleraceus\#, Papaver rhoeas\#, Anagallis arvensis, Arenaria serpyllifolia, Cerastium fontanum, Epilobium montanum, Helminthotheca echioides, Juncus bufonius, Lactuca virosa, Persicaria maculosa, Reseda luteola, Sagina filicaulis, Tripleurospermum inodorum, Triticum aestivum, Tussilago farfara

\# also a component species of NVC OV13 (Rodwell, 2000); Bold = species frequent or greater abundance in any area of woodland type; Underlined $=$ species occurred in all areas of woodland type.

A feature of the post translocation ground layer is the large number of such species which were not recorded pre-transfer, and particularly within the more 'open' W16 woodland type. However, more notably is the abundance of only a few species (i.e., spear thistle (Cirsium 
vulgare), prickly ox-tongue (Helminthotheca echioides), squirrel tail fescue (Vulpia myuros), sterile brome (Anisantha sterilis), Canadian fleabane (Conyza canadensis), and American willowherb (Epilobium ciliatum)) across the translocated areas.

In addition to the early successional/disturbed ground species, a large number of species that are associated with 'closed' grassland communities or a wider range of habitat types also occurred, and where creeping thistle (Cirsium arvense) and sticky mouse ear (Cerastium glomeratum) were prominent (Table 7).

Table 7. Herbaceous species associated with grasslands and wide range of habitats.

\begin{tabular}{|l|l|l|}
\hline \multicolumn{2}{|c|}{ Within W10 Areas } & Within W16 Areas \\
\hline $\begin{array}{l}\text { Grassland - Donor not } \\
\text { Receptor }\end{array}$ & $\begin{array}{l}\text { Other Habitats - Receptor } \\
\text { not Donor }\end{array}$ & $\begin{array}{l}\text { Other Habitats - Receptor } \\
\text { not Donor }\end{array}$ \\
\hline Crepis capillaris & $\begin{array}{l}\text { Cirsium arvense\#, } \\
\text { Cerastium glomeratum, }\end{array}$ & Cerastium glomeratum \\
\hline$\underline{\text { Scrophularia nodosa }}$ & \\
\hline
\end{tabular}

Less constant and frequent species: Grassland Species in W10 Areas - Donor not Receptor Agrostis vinealis, Hypochaeris radicata, Lotus corniculatus, Rumex acetosella, Taraxacum agg., Vicia hirsuta: Receptor not Donor Leucanthemum vulgare

Less constant and frequent species: Grassland Species W16 Areas - Receptor not Donor Agrostis vinealis, Crepis capillaris, Hypochaeris radicata, Leucanthemum vulgare, Lotus corniculatus, Ranunculus repens, Taraxacum agg., Vicia hirsute

Less constant and frequent species: Widely Occurring Species in W10 Areas - Donor not Receptor Aira praecox, Juncus bufonius: Receptor not Donor Poa annua\#, Lamium album\#, Carduus crispus, Epilobium parviflorum, Filago vulgaris, Myosotis arvensis, Veronica arvensis, Vulpia bromoides

Less constant and frequent species: Widely Occurring Species in W16 Areas - Donor and Receptor Poa annua\#: Donor not Receptor Rumex acetosa: After not Before Cirsium arvense\#, Lamium album\#, Aira praecox, Carduus crispus, Epilobium parviflorum, Filago vulgaris, Myosotis arvensis, Scrophularia nodosa, Veronica arvensis, Vulpia bromoides

\# also, a component species of NVC OV13 (Rodwell, 2000); Bold = species frequent or greater abundance in any area of woodland type; Underlined = species occurred in all areas of woodland type.

Invertebrate Monitoring

A total of 110 invertebrate species were recorded from the sweep-netted samples. These were grouped into their habitat associations (Drake et al., 2007), which coincidentally reflected their specific or broad associations with plant species; the four groupings were woodland, grassland, open early successional, or a wide range of habitat types. Whilst the recordings in the following tables might imply they are specific to their respective woodland NVC types, this is unlikely given the mobility of the almost entirely winged adults captured and could be a matter of chance given that not all the translocated areas were netted nor were all the netted captures identified. 
Potential Tree-Shrub Layer. Of the 11 species collected across the translocated areas (Table 8), seven (as one was common to both types of woodland areas) are considered as true arboreal species of an eclectic mixture consisting of common green lacewing (Chrysopa carnea), brimstone butterfly (Gonepteryx rhamni), common soldier beetle (Rhagonycha fulva), a spider (Aranniella cucurbitina), a parasitic fly (Phasia obesa), and two other flies (Nemorilla floralis and Phasia pusilla). Similarly, the winged adult saproxylic species (Hylaeus hyalinatus (masked bee), Lonchaea sp. (fly), Passaloecus gracilis (parasitic wasp) and Megachile ligniseca (bee)) were recorded within the NVC W10 and W16 woodland types.

Table 8. Arboreal and saproxylic species.

\begin{tabular}{|c|c|c|c|}
\hline \multicolumn{2}{|l|}{ Within W10 Areas } & \multicolumn{2}{|l|}{ Within W16 Areas } \\
\hline canopy & dead wood & canopy & dead wood \\
\hline $\begin{array}{l}\text { Chrysopa carnea } \\
\text { agg., Gonepteryx } \\
\text { rhamni, Rhagonycha } \\
\text { fulva, Phasia pusilla }\end{array}$ & $\begin{array}{l}\text { Hylaeus hyalinatus, } \\
\text { Lonchaea sp. (fe- } \\
\text { male) }\end{array}$ & $\begin{array}{l}\text { Araniella cucurbitina, } \\
\text { Rhagonycha fulva, Nemo- } \\
\text { rilla floralis, Phasia obesa }\end{array}$ & $\begin{array}{l}\text { Passaloecus } \\
\text { gracilis, } \\
\text { Megachile } \\
\text { ligniseca }\end{array}$ \\
\hline
\end{tabular}

Ground Layer. A total of 33 grassland/grassland-scrub mosaic species were collected with 19 species, ranging from butterflies, plant bugs, flies, hoverflies, bees, and a spider (Table 9).

Table 9: Invertebrate groups and species associated with grassland-scrub mosaics.

\begin{tabular}{|l|l|l|}
\hline Within W10 Areas & Within W16 Areas & \multicolumn{1}{c|}{ Common to Both } \\
\hline $\begin{array}{l}\text { Soldier Fly - Beris } \\
\text { vallata }\end{array}$ & $\begin{array}{l}\text { Butterflies - Maniola jurtina, } \\
\text { Pyronia tithonus, Lycaena } \\
\text { phlaeas, Thymelicus lineola, } \\
\text { Thymelicus sylvestris }\end{array}$ & $\begin{array}{l}\text { Butterflies - Aglais urticae, } \\
\text { Aphantopus hyperantus, }\end{array}$ \\
\hline $\begin{array}{l}\text { Gall Fly - Tephritis } \\
\text { ruralis }\end{array}$ & Bug- Eurydema oleracea & $\begin{array}{l}\text { Bugs - Closterotomus norwegicus, } \\
\text { Coreus marginatus, Heterotoma } \\
\text { merioptera, Liocoris tripustulatus, } \\
\text { Nabis ferus, Orthops kalmi, } \\
\text { Palomena prasina, Rhopalus } \\
\text { subrufus, Stenodema calcaratum }\end{array}$ \\
\hline & Gall Fly - Terellia ruficauda & Gall Fly - Tephritis formosa \\
\hline & $\begin{array}{l}\text { Flies - Tomosvaryella } \\
\text { sylvatica, Tephritis neesii, } \\
\text { Opomyza germinationis, } \\
\text { Phytomyza tussilaginis }\end{array}$ & Fly - Sphenella marginata, \\
& Bee - Hylaeus brevicornis & $\begin{array}{l}\text { Fruit Flies - Terellia longicauda, } \\
\text { Urophora stylata }\end{array}$ \\
\hline & & $\begin{array}{l}\text { Hoverflies - Syritta pipiens, } \\
\text { Xanthogramma pedissequum }\end{array}$ \\
\hline & & Bee - Bombus pascuorum \\
\hline & & Spider - Enoplognatha ovata \\
\hline
\end{tabular}

Bold $=$ more than 10 individuals in sub-samples 
The list (those in bold had more than 10 individuals recorded) included numbers of the true bugs Liocoris tripustulatus and Stenodema calcaratum, a gall fly Tephritis formosa and the fly Sphenella marginata. Only two, Beris vallata (a soldier fly) and Tephritis ruralis (a gall fly) were seemingly specific to the W10 areas, with 12, mainly butterflies and flies sampled from the W16 areas.

Out of a total of 21 species of early open successional habitats, 11 (plant bugs, ladybird beetle, hoverfly, and bees) were common to both NVC woodland types, with three (a seed bug and bees) solely with W10, and 7 (a butterfly, flies, hoverfly, and bees) with W16 areas (Table 10). Common to both woodland types are the notable (scarce) plant bug species (Stictopleurus abution and S. punctatonervosus) and the scarce variegated ladybug Adonia variegata.

Table 10. Invertebrate groups and species of early open-successional habitats.

\begin{tabular}{|l|l|l|}
\hline Within W10 Areas & Within W16 Areas & Common to Both \\
\hline Seed Bug - Nysius sp. & $\begin{array}{l}\text { Butterfly - Polyommatus ica- } \\
\text { rus }\end{array}$ & $\begin{array}{l}\text { Bugs - Corizus hyoscyami, } \\
\text { Rhopalus parumpunctatus, } \\
\text { Stictopleurus abutilon, Stic- } \\
\text { topleurus punctatonervosus }\end{array}$ \\
\hline $\begin{array}{l}\text { Bees - Hoplitis spinulosa, } \\
\text { Lasioglossum leucopus }\end{array}$ & $\begin{array}{l}\text { Gall Fly - Terellia tussi- } \\
\text { laginis }\end{array}$ & $\begin{array}{l}\text { Ladybird Beetle - } \text { Adonia } \\
\text { variegata }\end{array}$ \\
\hline Fly - Sicus ferrugineus & $\begin{array}{l}\text { Hoverfly - Sphaerophoria } \\
\text { scripta }\end{array}$ \\
& $\begin{array}{l}\text { Hoverfly - Eupeodes corol- } \\
\text { lae, }\end{array}$ & $\begin{array}{l}\text { Bees - Andrena minutula, } \\
\text { Nomada flavoguttata, Sphe- } \\
\text { codes monilicornis, Bombus } \\
\text { lapidaries, Bombus terrestris }\end{array}$ \\
\hline & $\begin{array}{l}\text { Bees - Andrena similis, La- } \\
\text { sioglossum albipes, Lasio- } \\
\text { glossum smeathmanellum }\end{array}$ & \\
\hline
\end{tabular}

Underlined $=$ notable (scarce) species

A total of 43 of the 110 invertebrate species recorded were associated with a wider range of habitats. Seven species were associated specifically with W10 areas, whilst 22 with W16, and 14 were common to both (Table 11). The latter were represented by numbers of individuals of the common blue damselfly Enallagma cynthigerum, the plant bug Lygus species, and the hoverfly Melanostoma mellinum. 
Table 11. Invertebrate groups and species associated with a range of habitats.

\begin{tabular}{|c|c|c|}
\hline Within W10 Areas & Within W16 Areas & Common to Both \\
\hline $\begin{array}{l}\text { Butterfly - Pieris bras- } \\
\text { sicae }\end{array}$ & $\begin{array}{l}\text { Dragonfly - Aeshna gran- } \\
\text { dis }\end{array}$ & $\begin{array}{l}\text { Damselfly - Enallagma cy- } \\
\text { athigerum }\end{array}$ \\
\hline $\begin{array}{l}\text { Soldier Fly - Oxycera } \\
\text { rara }\end{array}$ & Moth - Tyria jacobaeae & $\begin{array}{l}\text { Butterflies - Pieris napi, Pieris ra- } \\
\text { pae }\end{array}$ \\
\hline \multirow{8}{*}{$\begin{array}{l}\text { Flies - Sepsis punctum, } \\
\text { Sarcophaga carnaria, } \\
\text { Sarcophaga subvicina, } \\
\text { Morellia simplex, Mus- } \\
\text { ca autumnalis }\end{array}$} & $\begin{array}{l}\text { Predatory Bug - Anthoco- } \\
\text { ris nemorum }\end{array}$ & Moths - Zygaena sp. \\
\hline & $\begin{array}{l}\text { Ladybird Beetles: Harmo- } \\
\text { nia axyridis, Sapromyzo- } \\
\text { soma quadripunctata }\end{array}$ & Bug - Lygus sp. \\
\hline & Seed Fly - Delia florilega & Spittlebugug - Philaenus spumarius \\
\hline & $\begin{array}{l}\text { Predatory Fly - Rhagio } \\
\text { lineola }\end{array}$ & Beetle - Oedemera lurida \\
\hline & $\begin{array}{l}\text { Flies - Drapetis pusilla, } \\
\text { Chrysops caecutiens, Mi- } \\
\text { nettia fasciata, Scatella } \\
\text { tenuicosta, Rhinophora } \\
\text { lepida, Anthomyia con- } \\
\text { fusanea, Botanophila fu- } \\
\text { gax, Hylemyia urbica, } \\
\text { Paregle audacula, Coeno- } \\
\text { sia infantula }\end{array}$ & $\begin{array}{l}\text { Ladybird Beetles - Coccinella } \\
\text { septpunctata, Propylea quatuordec- } \\
\text { impunctata }\end{array}$ \\
\hline & $\begin{array}{l}\text { Hoverflies - Eristalis in- } \\
\text { terruptus, Eristalis tenax, } \\
\text { Neoascia podagrica }\end{array}$ & Fly - Chrysotus gramineus \\
\hline & $\begin{array}{l}\text { Bees - Andrena minuta } \\
\text { group, Colletes daviesi- } \\
\text { anus }\end{array}$ & $\begin{array}{l}\text { Hoverflies - Episyrphus balteatus, } \\
\text { Melanostoma mellinum }\end{array}$ \\
\hline & & $\begin{array}{l}\text { Parasitic Wasps - Diplazon laetato- } \\
\text { rius, Pimplinae }\end{array}$ \\
\hline
\end{tabular}

Bold $=$ more than 10 individuals in sub-samples

\section{$\underline{\text { Discussion }}$}

There are very few accessible and informative first-hand accounts of woodland translocation schemes, those available are of schemes undertaken some time ago in the 1980s, and are referred to below in the course of this discussion. Other translocations have taken place more recently, but there is no publicly available information from which to learn. Hence, the reporting of the recent translocation at Mountsorrel is of value and timely because of the likely impact of developments such as the HS2 rail scheme on a multitude of ASNWs (UK Government, 2017). 
The first year of monitoring at Mountsorrel is considered to be of greater value than might be first thought in helping to understand the likely future success of the translocation, the measures and commitments that might be needed to promote the achievement of its aims, and from which useful lessons can be learnt for future woodland translocation schemes. The lessons learnt here have been adopted in the follow-on second phase of translocation of woodland from the southern quarry rim (SER) in 2018.

\section{Monitoring and its Evaluation}

Use and Interpretation of the First Year of Monitoring. At Mountsorrel the aim was to reestablish woodland of a similar kind as possible to the Donor, as the 'whole wood', its ground, shrub, and tree layer components. The results presented here are just of one year of monitoring at the very start of the woodland regeneration processes. For oak woodland of a similar structural condition as the Donor areas this is some 70 years into the future. From previous experiences reported for woodland translocations it is likely that it will be one or two decades before a functional canopy is likely to have developed (Anderson, 2003; Craig et al., 2015; Buckley et al., 2017). The data from these reports suggest that the initial vegetation, even after 1-3 years, can be indicative of the type and nature of the future woodland. Egler (1954) set out the conceptual model of Initial Floristic Composition (IFC) as applied to old-field secondary succession where the early expression of species presence is indicative of subsequent plant community composition. This model has been adopted in the re-afforestation of bauxite mined land in the jarrah forest in Western Australia (Norman et al., 2006; Koch, 2017), where evaluation by the regulatory authority and the mining company need only take place after 1 or 2 years of recruitment from sown seed and plantings (A. Grigg, Personal Communication). The validity of the rationale is supported by other experiences in Australia that initial sowing/planting determines at least the first generation of the new woodland community and structure (Humphries, 2016). The experiences at Brickhouse Wood, Biggins Wood, Mold By-Pass, Stansted Airport have also shown that the commoner occurring ground layer species in the woodlands present in the first year of translocation generally survived to and beyond the development of a canopy in ten to twenty years later (Anderson, 2003; Craig et al., 2015; Buckley et al., 2017). However, longer-term monitoring has demonstrated that caution is needed, as the intended developing community may not happen, without intervention, owing to the dominance of some of the component species (Humphries, 2016). Anderson (2003) and Craig et al. (2015) refer to the competitiveness of re-establishing species such as grass H. mollis, the soft-rush Juncus 
effusus, and the thistle C. arvense during the first four years after translocation, and Anderson (2003) and Buckley et al. (2017) to later, years 6-11, competition from the scrambling small shrub $R$. fruticosus prior to tree/shrub canopy development. The latter can also be a feature of regenerating felled and coppiced woodlands (Peterken and Mountford, 2017).

The translocated woodland at Mountsorrel has the composition and form described by Kirby (1990) of clear-felled woodland with the ground flora layer being dominant. The common practice of using mature woodland as reference sites for evaluation purposes has been questioned (Humphries, 2015), where immature stands in a similar state, and where the outcome can be reasonably predicted, are likely to be the more appropriate. In the case here, the composition of the initial post translocation vegetation as reported by Craig et al. (2015) and Buckley et al. (2017) are relevant and for the reasons set out above, can be applied to the interpretation of the first year of monitoring at Mountsorrel.

Future Monitoring. Although the vascular plant lists were compiled on just one day of recording of the entire area of translocated woodland at the receptor site, they are probably representative of the plant components present after translocation. From other studies of the recovery of both felled and translocated woodland, the rate of changes in plant composition and woodland recovery are relatively slow with discernible development occurring after 5 and 10 years following the development of shade conditions from a tree/shrub canopy (Kirby, 1990; Craig et al., 2015; Buckley et al., 2017; Peterken and Mountford, 2017). Hence, further formal monitoring of vascular plants is planned at Mountsorrel in 5-, 10-, and 15years' time, thereafter, the case for further monitoring would be reviewed. Although the list of invertebrates indicates an early presence, it is certainly not complete as the translocated area was only sampled by one method and at one time of the year when not all species were likely to be present in a collectable form (Drake et al., 2007). However, they indicate early colonisation and a composition reflecting the habitat conditions and vascular plant composition established. The presence of arboreal invertebrate species is probably a result of opportunistic immigration from the adjacent Buddon Wood, or elsewhere, rather than their translocation. Some like the dragon/damselflies were clearly ranging from their nearby wetland habitats. Further monitoring for less mobile 'ground living' species and larvae, by pitfall trapping, collection of dead wood samples for the rearing of saproxylic species, and sweep netting at a different time of the year is planned for 2019, and subsequently is to be repeated in concert with the vascular plant recording in years 5, 10 and 15 . 


\section{Tangible Translocation of Woodland Types}

Representative Species. The presence of representative vascular plant species typical of both NVC W10 and W16 woodland types within the translocated areas at Mountsorrel is indicative, even at this early stage and irrespective of a few species not being transferred, that there is a tangible basis for their re-establishment, albeit not an exact replica. The few species not re-establishing are considered to have been of infrequent occurrence, as has been reported as the case for translocated ground layer species elsewhere, and would not be expected to survive the bulk soil handling method of transfer (Craig et al., 2015; Buckley et al., 2017). Here, for important species of particularly infrequent occurrence and for those species that are difficult to re-establish, rescue or propagation programmes may be necessary (Down and Morton, 1998; Humphries, 2001; Koch, 2007).

The establishment and presence at Mountsorrel of 'self-sown' B. pendula and Q. petraea and other tree/shrub seedlings, and the epicormic sprouting of (some) transferred Q. petraea tree monoliths is indicative that the tree layer has the potential to recover and ultimately develop a woodland canopy cover as reported by Peterken and Mountford (2017). Down and Morton (1998) report that in the short-term all twelve transferred coppiced (pollarded) trees/shrubs survived, and although their monitoring was suspended after 2 years, they considered that their longer-term survival was likely. Hence, translocation is not dissimilar to forestry clear felling/coppicing operations, as has been the situation following the last clear felling of Buddon Wood in the 1940s.

Establishment of Non-Woodland Flora. A feature of the Mountsorrel translocation was the substantially large number of plant species present than recorded in the Donor areas; in particular those associated with open woodland margins and glades, grasslands and disturbed land, and notably annuals and biennials of disturbed ground. The list of associated invertebrate species at Mountsorrel reflected those of woodland margins, glades/grasslands. Large increases in plant species associated with such open and disturbed habitats has also been reported following the translocation of (coppice) woodland soils (Helliwell et al., 1996; Anderson, 2003; Craig et al., 2015; Buckley et al., 2017), but also following the forestry practices of coppicing and the clear felling of woodland owing to the disturbance of the ground layer and soils (Kirby, 1990). In both cases it has been shown from soil samples that regeneration was taking place from the seed-bank. 
The longer list of species for the W16 areas than the W10 (even though they are adjacent to each other) at Mountsorrel can be explained by W16 ground cover being more 'open' and more prone to immigration than that for W10. The Donor woodland along the quarry edge had been 'opened up' from previous stone extraction and exposed to more light and invasion by species with wind-borne seed, particularly from the edge of the quarry workings where mineral spoil had been used to raise 'safety-bunds' and was colonised by several of the nonwoodland species. The translocation process results in the disturbance of the woodland soil and initially bare ground which would promote plant establishment from their 'seed-bank'. Their later arrival following translocation is also feasible as the disturbed soil on translocation would provide suitable conditions for invasive plant species to establish. It had been noted that invasive plant species were in the vicinity of the Receptor area, hence the need for measures to be in place to control them (see below).

\section{$\underline{\text { Intervention as Normal Practice }}$}

Intervention during the preparation for the implementation of the translocation of habitats, and subsequently, is likely to be required on several accounts (Humphries et al., 1995; Down and Morton, 1998; Anderson, 2003; Humphries, 2016; Buckley et al., 2017). This includes the likely coppicing/pollarding of trees/shrubs to be transferred, control of invasive competitive species and browsing mammals, and the later management of the structural architecture of the developing woodland.

Control of Invasive Competitive Species. Invasive alien and native plants have become a global problem in the conservation of natural ecosystems (Keller et al, 2015) and are also a significant impediment in the successful management and restoration of native ecosystems (Shelly et al., 1996). Vasquez and Shelly (2018) reminded us of the importance and effectiveness of proactively managing invasive plants on active and restored mine sites, rather than more costly and often fewer effective measures when reacting to infestations at a later time. Depending on the dominance of the non-woodland flora and the effect they have on plant growth resources (light, nutrient and water), without intervention they could alter the direction of future vegetation/woodland development. An investigation of a number of translocation schemes in 1991 (Humphries et al., 1995) indicated that pre- and post-transfer management was a key factor and can be of over-riding importance in their success. Such was the recruitment and growth of competitive non-woodland flora at the Biggins Wood translocation that cutting and herbicide treatments had to be introduced (Buckley et al., 2017). Helliwell et al. (1996), Craig et al. (2015) and Buckley et al. (2017) demonstrated that 
the in-situ seed banks were significant sources of non-woodland (annual, biennial, and ruderal) species. Clear felling and coppicing operations, and the concomitant disturbance of the soil, created conditions for invasive species and their seed banks (Kirby, 1990; Craig et al., 2015).

A proactive programme was not possible at Mountsorrel as infestation of the Donor areas by invasive non-native tree and shrub species (A. pseudoplatanus, $R$. ponticum/P. laurocerasus, and B. davidii) and a number of invasive herbaceous species (e.g., C. vulgare, cleavers (Galium aparine) and field sow-thistle (Sonchus arvensis)) had already taken place owing to the exposure to immigration through the previous removal and disturbance of the woodland edge, and the colonisation of the placed materials as a 'safety-bund'. In response, the translocation of the invasive shrubs within the Donor area was largely avoided during the removal process by working around the shrubs or selectively digging out and placing them to one side for later disposal. The safety-bunds with their colonists remained undisturbed throughout the translocation process, when they were removed during the extension of the quarry rim into the former woodland and the formation of a new bund at the new woodland edge. The above illustrates the importance of extending the proactive invasive plant management programme to the exposed margins of important habitats exposed during land development, and for materials or structures that are introduced along their margin and which facilitate infestations.

Provisions for post-translocation management were anticipated as not all invasive tree, shrub and herbaceous species being present could have been avoided along with the anticipated recruitment from the accumulated seed bank. Cirsium species were the most prominent, but were dispersed as individuals throughout the woodland. Avoidance of these and other weedy herbaceous species was not practical during the translocation process and hence the post-translocation management programme of hand-pulling and removal. Of particular concern were the rapidly growing non-native shrubs which, without intervention, would develop dense stands shading-out the recovering native woodland flora and result in dense mono-specific stands (Humphries, 2016). Others, such as the tree species $A$. pseudoplatanus (which are non-native, but considered by many to be naturalised) are listed as components in woodlands and scrub (Rodwell, 1991), may out-compete the native tree species without materially altering the woodland plant community type. It was anticipated that some material in the form of root fragments or dispersed seed would be transferred and a programme of either hand-pulling (A. pseudoplatanus, B. davidii) or herbicide treatment $(R$. 
ponticum/P. laurocerasus) of re-establishing plants was planned and undertaken in the first year of translocation.

The newly translocated areas are obviously prone to regeneration of invasive species not only from the transferred seed bank, but are receptive to invasion from locally infested areas. A number of invasive non-woodland species occurred around/near to the receptor area, which included the alien shrub B. davidii and several invasive herbaceous species (e.g. fat hen (Chenopodium album), Cirsium spp., and Sonchus spp.). During 2018 a programme to eradicate/minimise the invasive species within and immediately around the translocation areas was implemented in March, April, June, and August. In the immediate vicinity of the translocated woodland, all B. davidii and C. album plants were to be removed and Cirsium species to be sequentially reduced to $50 \%$ of their number by hand-pulling. The need for this action emphasised that sources of potential infestation next to and around the translocated woodland have to be considered to be a risk and should be proactively managed. In this case it was a sediment lagoon, the operational overburden mound, the nearby soil storage mounds, and the peripheral ground immediately around the translocation area. Historically, during the operational phase of the quarry development, only the soil mounds are usually subject to a formal management programme for weed species with other areas being managed as 'necessary.' This approach has been changed to proactively managing these areas to reduce the potential for infestation and invasion of the translocated woodland until the restoration of the site is complete. Thereafter, the control of invasive species might be expected to become the responsibility of the successor land owner or tenant.

Control of Mammal Browsing. Other influences on the regeneration and development of woodland are browsing (deer, rabbits, squirrels, voles), invertebrate infestations, fungal and bacterial diseases, and management history (Peterken and Mountford, 2017). The browsing of woodland is well known to inhibit tree and shrub regeneration, and affect the ground flora composition. Muntjak deer and rabbit are present in Buddon Wood, and are grazing in the translocated areas. Anderson (2003) refers to the impact of grazing on translocated woodland at Stansted Airport. At Mountsorrel, steps have been taken to protect young tree saplings over the winter 2018-2019 by installing plastic-net tree guards around them.

\section{Implications for Future Woodland Translocations}

Presently, at Mountsorrel there appears to be sufficient potential regeneration of the tree and shrub layers as not to need supplementary planting. This is contrary to the view that trees and shrubs of similar woodlands could not be moved and had to be replaced as planted 
nursery-grown stock (Helliwell et al., 1986; Craig et al., 2015; Buckley et al., 2017), although as Anderson (2003) commented about the Stansted Airport scheme, this is governed by the size and type of machines available. Subject to the safe use of machines to recover the soils and vegetation (Humphries et al., 2018), the translocation at Mountsorrel Quarry demonstrates that it is physically feasible to move a woodland flora with its shallow top-soils and component tree and shrub flora (provided they are coppiced) without undue operational difficulty. A similar view for the transplanting of the tree canopy component has been expressed by Down and Morton (1998) and Anderson (2003).

In the case of the Mountsorrel scheme, the prime reason for transferring the pollarded trees was to provide woody habitat for saproxylic invertebrate species (Stokland et al., 2012), which are a feature of Buddon Wood (Natural England, Undated), something that otherwise would take decades to 'regrow' by planting nursery stock (Humphries, 2013). The trees were simply 'dug' (taking as much of the root-plate that broke away with the tree trunk) with the excavator bucket, loaded and carried by dump truck to the Receptor area, and 'planted' as monoliths. Several monoliths subsequently sprouted new shoots and have seemingly survived the transfer suggesting that with a modified approach more of the transferred mature trees might have re-sprouted as they obviously did follow the previous felling in the 1940s, and as Down and Morton (1998) report for the mature trees they transplanted by a similar method. Hence, precursors to the re-establishment of woodland of ancient semi-natural types, and key vegetation features of their ecosystems, as found in Buddon Wood SSSI, can be translocated.

\section{$\underline{\text { Conclusions }}$}

The monitoring in the first year following translocation of the woodland at Mountsorrel has been of particular importance in the delivery of the approved relocation scheme as it identified that the representative species, which are needed to re-establish and develop into similar woodland communities to those of the donor, are present. It also determined the need and focus for the subsequent control of invasive species, and other actions that will be needed to achieve the longer-term objective.

A key outcome is the need for a programme of proactive management of invasive plant species in the vicinity of both the donor woodland and the receptor site, prior to, during and after translocation. Particular attention needs to be given when edges of woodlands are opened up to immigration from adjacent habitats, and readily colonisable materials and 
surfaces (e.g., safety bunds, soil storage mounds, haul routes) are introduced alongside the donor and receptor areas during the development and before restoration/mine closure. The process is not specific to developments, as it also occurs during forestry/woodland practices of clear-felling operations or coppice rotations.

Mountsorrel also demonstrates that the recovery and transfer of the mature tree and shrub components is technically achievable without undue difficulty. Hence, the translocation of the 'whole woodland' vascular plant assemblage is more feasible than previously canvassed, and something that is equivalent to normal woodland practices of clear-felling operations or coppice rotations.

The primary case against woodland translocations are that i) the historical connection is broken and ii) the vegetation and its soils have taken centuries to develop a stable ecosystem and so they cannot be recreated. The initial results of the translocation at Mountsorrel Quarry and the published literature suggest the latter argument might not necessarily be the case, nor would the former should successful translocation take place within the historical footprint of the donor wood. Consequently, in the appropriate circumstances, woodland translocations might be considered as a more justifiable and deliverable means of compensation and facilitation for development.

Although this paper reports on a single year of monitoring, it highlights useful lessons that are of current and wide relevance to the mining/quarrying industry, and other developments such as HS2 in the UK and elsewhere.

\section{Acknowledgements}

We thank Tarmac Ltd and David Park of Tarmac for encouraging us to present and publish this paper. The Mountsorrel Quarry woodland translocation scheme has involved a number of Tarmac's senior management and technical support staff, and other organisations. We acknowledge their contribution in making it a successful operation and in particular thank Trevor Warren, Shane Tompkin, Tim Deal, Andy McIntosh, and Gareth Burdell of Tarmac; Jim Meadowcroft of David Jarvis Associates; Andy Hawkes and the earth moving machine operators of Chepstow International Plant Hire; and Ian Johnson and staff of Planterior.

The species recording was carried out by professional specialists; the vascular plants in 2014 by Paul Benyon (Leverton Land Quality Surveys) and in 2018 by Mark Woods (Baker Consultants Ltd), and the invertebrates by Andy Godfrey (Andy Godfrey Associates). 


\section{$\underline{\text { References }}$}

Aggregate Business. 2019. Looking into the future at Mountsorrel. http://www.aggbusiness.com/sections/quarry-profiles-reports/features/looking-into-thefuture-at-mountsorrel/ Viewed $29^{\text {th }}$ March 2019.

Anderson, P. 2003. CD-ROM: A Review of Habitat Translocation. CIRIA, London UK.

Buckley, G. P., D. R. Helliwell, S. Milne, and R. Howell. 2017. Twenty-five years on vegetation succession on a translocated ancient woodland soil at Biggins Wood, Kent, UK. Forestry: An International Journal of Forest Research, 90, 4, 561-572. https://doi.org/10.1093/forestry/cpx015

Bullock, J. M. 1998. Community translocation in Britain: Setting objectives and measuring consequences. Biological Conservation, 84, 3, 199-214. https://doi.org/10.1016/S00063207(97)00140-7

Craig, M., P. Buckley and R. Howell. 2015. Responses of an ancient woodland field layer to soil translocation: methods and timing. Applied Vegetation Science, 18, 579-590. https://doi.org/10.1111/avsc. 12170

Down, C. G. and A. J. Morton. 1989. Chapter 19: A case study of whole woodland transplanting, p 251-257. In Buckley G. P. (ed), Biological Habitat Reconstruction. Belhaven Press, London, UK.

Drake, C. M., D. A. Lott, K. N. A. Alexander, and J. Webb. 2007. Natural England Research Report NERR005: Surveying terrestrial and freshwater invertebrates for conservation evaluation. Natural England, Peterborough UK.

Egler, F.E. 1954. Vegetation science concepts I. Initial floristic composition, a factor in oldfield vegetation development. Vegetatio Acta Geobot, 4, 6, 412-417. https://doi.org/10.1007/BF00275587

Glassball Art Projects. 2012. Mountsorrel Arts and Heritage Project: Memories of Stone, Steam and Steel. Graphicom, Vicenza, Italy.

Keller, R. P., M. V. Cadotte, and G. Sandiford. 2015. Invasive Species in a Globalized World: Ecological, Social and Legal Perspectives on Policy. University of Chicago Press, USA.

Helliwell, D. R., G. P. Buckley, S. J. Fordham, and T. A. Paul. 1996. Vegetation succession on a relocated ancient woodland soil. Forestry: An International Journal of Forest Research, 69,1, 57-74. https://doi.org/10.1093/forestry/69.1.57 
High Speed 2 Limited. 2017. High Speed Two Phase One: London-West Midlands Ancient Woodland Strategy https://assets.publishing.service.gov.uk/government/uploads/system/uploads/attachment data/file/664737/hs2_phase_one_ancient_woodland_strategy.pdf Viewed 3rd April 2019.

Hains, B. A. and A. Horton. 1969. British Regional Geology: Central England. Institute of Geological Sciences. HMSO, London, UK.

Humphries, R. N. 2001. Biodiversity: Approaches to Diversity. Mining Quarrying and Recycling, 30, 1, 33-37.

Humphries, R. N. 2013. Understanding and delivery of the components of structure, diversity, and function in the restoration of ecosystems on mined land: working towards a practical methodology. Journal American Society of Mining and Reclamation, 2, 2, 1-31. http://doi.org/10.21000/JASMR13020001

Humphries, R. N. 2015. Use of reference sites in the evaluation of some rehabilitated native forests on surface mines in Australia. Journal American Society of Mining and Reclamation, 4, 2, 36-54. http://doi.org/10.21000/JASMR15020036

Humphries, R. N. 2016. Case study: some lessons from the early development of native forest rehabilitation at three surface mine complexes in Australia. Journal American Society of Mining and Reclamation, 5, 1, 1-27. http://doi.org/10.21000/JASMR16010001

Humphries, R. N., P. J. Horton, and P. R. Benyon. 1995. Transplantation of grasslands: I. The importance of traditional management practices. p186-193. In Proceedings of the National Meeting of the American Society for Surface Mining and Reclamation, Gillette, Wyoming, June 5-8, 1995. https://doe.org/10.21000/JASMR95010186

Humphries, R. N., P. Close, and R. J. Smallshaw. 2018. The Selection and Operation of Earth Moving Equipment for the Rehabilitation of Functional Soil Profiles: An updating of the UK guidance. Journal American Society of Mining and Reclamation, 7, 2, 1-18. DOI: http://dx.doi.org/10.21000/JASMR18020001

McLean, I. 2001. Committee Paper: Biological translocations policy paper, December 2001. Joint Nature Conservation Committee. http://jncc.defra.gov.uk/pdf/comm01P25.pdf Viewed 25th March 2019. 
Kirby, K. J. 1990. Changes in the Ground Flora of a Broadleaved Wood within a Clear Fell, Group Fells and a Coppiced Block. Forestry: An International Journal of Forest Research, Volume 63, 3, 241-249. https://doi.org/10.1093/forestry/63.3.241

Koch, J. M. 2007. Restoring a jarrah forest understory vegetation after bauxite mining in Western Australia. Restoration Ecology, 15, 4 (supplement), S26-S39.

Natural England, Undated. Buddon Wood and Swithland Reservoir SSSI: Citation. https://designatedsites.naturalengland.org.uk/PDFsForWeb/Citation/1003516.pdf Viewed $25^{\text {th }}$ March 2019.

Norman, M.A., J. M. Kock, C. D. Grant, T. K. Morald, and S. C. Ward, 2006. Vegetation succession after bauxite mining in Western Australia. Restoration Ecology, 14, 278-288. https://doi.org/10.1111/j.1526-100X.2006.00130.x

Park, D G. 1989. Chapter 21: Relocating magnesian limestone grassland. p264-280. In Buckley, G. P. (ed), Biological Habitat Reconstruction. Belhaven Press, London, UK.

Peterken, G. F. and E. P. Mountford. 2017. Woodland Development - A long term study of Lady Park Wood. CABI, Wallingford, UK.

Rodwell, J. S. (ed). 1991. British Plant Communities: Volume 1, Woodlands and Scrub. CUP, Cambridge.

Rodwell, J. S. (ed). 2000. British Plant Communities: Volume 5, Maritime communities and vegetation of open habitats. CUP, Cambridge.

Rodwell, J. S. 2006. National Vegetation Classification: Users' handbook. JNCC, Peterborough.

Ryan, L. 2013. Translocation and Ancient Woodland: assessing the evidence. https://www.woodlandtrust.org.uk/publications/2013/04/translocation-and-ancientwoodland/ Viewed 25 $5^{\text {th }}$ March 2019.

Sheley, R.L., T.J. Svejcar, and B.D. Maxwell. 1996. A theoretical framework for developing successional weed management strategies on rangeland. Weed Technology 7:766-773. https://doi.org/10.1017/S0890037X00040793

Stokland, J. N., J. Siitonen, and B. G. Jonsson. 2012. Biodiversity in Dead Wood. CUP, Cambridge, UK. 
Journal American Society of Mining and Reclamation, 2019 Vol.8, No.3

The Woodland Trust. 2014. Position Statement: Ancient woods and translocation. http://www.woodlandtrust.org.uk/publications/2014/10/ancient-woodland-andtranslocation/ Viewed $3^{\text {rd }}$ April 2018.

UK Government, 2017. Policy paper: HS2 Ancient Woodland Strategies. https://www.gov.uk/government/publications/hs2-phase-one-ancient-woodland-strategy Viewed $3^{\text {rd }}$ April 2019.

UK Government, 2018. Guidance: Planning applications affecting trees and woodland. https://www.gov.uk/guidance/planning-applications-affecting-trees-and-woodland Viewed $25^{\text {th }}$ March 2019.

Vasquez, E. A. and R. L. Shelly. 2018. Developing diverse, effective, and permanent plant communities on reclaimed surface coal mines: restoring ecosystem function. Journal American Society of Mining and Reclamation, 7, 1, 77-109. http://doi.org/10.21000/JASMR18010077 